\title{
Strategi Pengelolaan Usaha Mikro Kecil Dan Menengah (UMKM) Di Era Pandemi Corona Virus Disease (Covid -19)
}

\author{
Muhammad Amir Arham ${ }^{1}$, Mattoasi ${ }^{2}$, Rio Monoarfa ${ }^{3}$, Siti Pratiwi Husain ${ }^{4}$, \\ Amir Lukum ${ }^{5}$ \\ ${ }^{1,2}$ Universitas Negeri Gorontalo, Jl. Jend. Sudirman No.6, Dulalowo Tim., Kota Tengah, \\ Kota Gorontalo, Gorontalo 96128, Indonesia \\ email: muhammad.arham@ung.ac.id
}

\begin{abstract}
The Covid-19 pandemic has had a huge impact on the national economic sector. how not, the MSME sector, which has been tested gradually over several times the economic crisis has hit Indonesia, but the Covid-19 pandemic has succeeded in overthrowing this sector. Not a few MSME players had to go out of business, and experienced a drastic drop in turnover. The purpose of carrying out this service activity is to help solve MSME problems, including strategies for running a business during the pandemic, MSME financial management, and access to capital. This service activity succeeded in providing development based on problem formulations obtained from processed data from interviews and direct observations.
\end{abstract}

\begin{abstract}
Abstrak
Pandemi Covid-19 sangat berdampak pada sektor ekonomi nasional.bagaiamana tidak, sektor UMKM yang telah teruji bertahap selama beberapa kalinkrisis ekonomi melanda Indonesia, namun pandemic Covid-19 berhasil menumbangkan sektor ini. tidak sedikit pelaku UMKM yang harus gulung tikar, dan mengalami penurunan omset yang begitu drastis. Tujuan dilaksanakan kegiatan pengabdian ini adalah untuk membantu menyelasaikan persoalan UMKM baik meliputi strategi menjalankan bisnis dimasa pandemi, manajemen keuangan UMKM, dan akses modal.Kegiatan pengabdian ini berhasil memberikan pembinaan berdasarkan rumusan masalah yang diperolah dari olahan data hasil wawancara dan observasi secara langsung.
\end{abstract}

(C) 2020 Muhammad Amir Arham, Mattoasi, Rio Monoarfa, Siti Pratiwi Husain, Amir Lukum Under the license CC BY-SA 4.0 Correspondence author: Muhammad Amir Arham, muhammad.arham@ung.ac.id, Gorontalo, and Indonesia 


\section{Pendahuluan}

UMKM memiliki potensi yang besar untuk dapat membantu pemerintah mengentaskan kemiskinan di Indonesia (Erwan-Agus,2007). Sebab menurutnya potensi tersebut salah satunya adalah dalam memberi kesempatan kerja pada jutaan penduduk di Indonesia yang tidak tertampung di sektor industri atau sektor usaha besar, penciptaan Produk Domestik Bruto, dan mendorong eksport. Sayangnya menurut Benny; IdaBudiarty dan Irma (2019) dan Gangi, Meles, Monferrà, \& Mustilli (2018) potensi tersebut selama ini kurang dikelola dengan baik karena perhatian pemerintah lebih kepada para pengusaha besar daripada perusahaan mikro, kecil dan menengah. Berkaitan dengan urgensi UMKM juga menurut Lies dan Devi-Agustien (2019); Haryono (2016) tidak tepat karena ternyata proteksi terhadap perusahaan besar (jasa,dagang dan Industri) kadang kala tidak dapat menopang perekonomian terutama pada saat terjadi resesi ekonomi. Bahkan menurut Lies dan Devi-Agustien (2019); Ghassani, 2015) serta Grootaert, Narayan, Jones, Woolcock (2004) menyatakan bahwa pada saat krisis global melanda dunia, kontribusi UMKM dalam roda perekonomian Indonesia masih berdiri tegak. Oleh karena itu para pelaku UMKM harus dibekali berbagai keahlian agar usaha yang dikelola setiap tahun mengalami perkembangan.

Namun demikian, dengan usaha untuk memaksimalkan peran dan fungsi UMKM ditengah-tengah masyarakat, akhirnya beberapa UMKM tidak maksimal karena di derah wabah Pandemi covid-19 sangat berdampak pada berbagai sektor terutama di sektor ekonomi salah satunya pada usaha mikro kecil menengah (UMKM). Dalam situasi pandemi ini, menurut Bappenas, 2017 bahwa terdapat sekitar 37.000 UMKM yang memberikan laporan bahwa mereka terdampak sangat serius dengan adanya pandemi ini ditandai dengan: sekitar 56 persen melaporkan terjadi penurunan penjualan, 22 persen melaporkan permasalahan pada aspek pembiayaan, 15 persen melaporkan pada 
masalah distribusi barang, dan 4 persen melaporkan kesulitan mendapatkan bahan baku mentah. Usaha mikro, kecil dan menengah (UMKM) berada di garis depan guncangan ekonomi yang disebabkan oleh pandemi COVID-19.

Kebijakan Pembatasan Sosial Berskala Besar (PSBB) yang diterapkan di beberapa wilayah di Indonesia. Merujuk pada Peraturan Menteri Kesehatan No. 9/2020 tentang Pedoman PSBB dalam rangka Percepatan Penanganan COVID-19, PSBB meliputi pembatasan kegiatan tertentu penduduk dalam suatu wilayah yang diduga terinfeksi COVID-19 termasuk pembatasan terhadap pergerakan orang dan/atau barang untuk satu provinsi atau kabupaten/kota tertentu untuk mencegah penyebaran COVID19. Erwan-Agus (2007); Benny; Ida-Budiarty dan Irma (2019) serta Lies dan Devi-Agustien (2019) langkah-langkah penguncian (lockdown) telah menghentikan aktivitas ekonomi secara tiba tiba, dengan penurunan permintaan dan mengganggu rantai pasokan di seluruh dunia. (Thaha, 2020)

Beberapa bidang ada yang mengalami kerugian dan ada yang mengalami keuntungan selama adanya pandemi covid 19.Pada UMKM yang terbagi di beberapa sektor yang berbeda juga merasakan dampak dari covid 19. Oleh karena itu UMKM perlu melakukan strategi untuk tetap mempertahankan keberlanjutan usaha selama pandemi dan tetap eksis setelah pandemi covid-19 ini berakhir. (Agustina Prativi Nugraheni, 2020)

Berdasarkan latar belakang dan fenomena yang terjadi bahwa covid19 membawa dampak buruk terhadap keberlangsungan usaha UMKM sehingga banyak dalam situasi pandemi ini, menurut Kemenkop UKM ada sekitar 37.000 UMKM yang memberikan laporan bahwa mereka terdampak sangat serius dengan adanya pandemi ini. Bahkan dalam proses pengelolaan UMKM yang masih dinilai rendah oleh beberapa hasil kajian sebelum ini, maka pada program KKN pada tahun ini kami ingin melakukan sebuah pengabdian dalam rangka membantu Usaha-usaha mikro kecil menengah di Provinsi Gorontalo yang lebih dikhususkan pada Desa Molutabu, Desa Helumo, dan Kelurahan Oluhuta di Kabupaten Bone 
Bolango, dalam memberikan informasi atau pengetahuan dan bagaimana strategi mereka dalam meningkatkan kinerja dan kompetensi di era pandemi covid-19.

Pada tahap pelaksanaan pengabdian, observasi dan wawancara dimasukkan menjadi salah satu tahap yang harus dilaksanakan pada kegiatan ini guna mencari apa saja masalah yang tengah dihadapi UMKM disamping melakukan studi literatur dan kajian terhadap beberapa penlitian terkait dan disesuaikan dengan karakteristik UMKM di tempat pengabdian, yakni desa Molutabu Kecamatan Kabila Bone, Desa Helumo Kecamatan Suwawa, dan Kelurahan Oluhuto Kecamatan Kabila.

Masalah besar yang ditemui para pelaku UMKM di Lokasi Pengabdian adalah tentang kurangnya pengetahuan masyarakat tentang strategi pengelolaan bisnis dimasa Pandemi Covid-19, Manajemen Keuangan UMKM, dan akses modal yang masih sulit untuk didapatkan. Maka dari itu melalui kegiatan ini kami merancang usulan kegiatan pemevahan masalah diantaranya :

1. Memberikan pemahaman dan penyuluhan terhadap masyarakat pelaku UMKM yang dikemas dalam bentuk kegiatan pelatihan. Dan materi yang disajikan diantaranya a) Manajemen Keuangan UMKM yang dibawakan oleh Akademisi Universitas Negeri Gorontalo, b) Strategi bisnis dimasa Pandemi Covid-19 yang dibawakan oleh Dra. Harnida A.G Mustapa selaku Owner dari Harnida Craft and Karawo, dan c) Sosialisasi Kredit Usaha Rakyat (KUR) oleh Ramdan Popitod Selaku Relationship Manager BANK BRI Cab. Gorontalo.

2. Memberikan pendampingan pada para pelaku UMKM meliputi pembuatan Laporan Keuangan UMKM, dan Melakukan monitoring secara berkala. 


\section{METODE PELAKSANAAN}

1. Observasi dan wawancara

Persiapan awal KKN meliputi observasi wilayah, observasi kegiatan ekonomi masyarakat, serta penyusunan program kerja KKN. Observasi wilayah dilakukan untuk mengetahui letak dusun serta penyebaran UMKM yang ada di Desa Helumo, Desa Molutabu dan Kelurahan Oluhuta, tujuannya agar mahasiswa dapat menganalisis persebaran UMKM yang dapat dikembangkan dan diberdayakan secara maksimal dalam rangka meningkatkan kualitas UMKM dimasa pandemi Covid-19.

Observasi kegiatan ekonomi masyarakat dilakukan untuk mengetahui sumber daya manusia selaku pelaku Usaha Mikro Kecil Menengah (UMKM), sehingga hal tersebut bisa menjadi acuan bagi mahasiswa dalam melaksanakan program kerja.Penyusunan program kerja KKN dilakukan berdasarkan hasil dari analisis observasi wilayah dan kegiatan ekonomi masyarakat.Mahasiswa diharapkan dapat membuat program-program yang kiranya dapat dimanfaatkan dalam memaksimalkan potensi UMKM khususnya dalam pengelolaan keuangan serta promosi digital dimasa pandemi Covid-19. Setelah Observasi dilakukan selanjutnya melakukan wawancara kepada para pelaku UMKM

1. Merumuskan Masalah

Tahap kedua yaitu merumuskan permasalahan apa saja yang dihadapi para pelaku UMKM berdasarkan hasil observasi lapangan dan wawancara.

2. Memberikan Pelatihan

Tahap yang ketiga yakni menyelenggarakan pelatihan strategi pengelolaan UMKM di era pandemic covid-19 guna menjawab permasalahan para pelaku UMKM. Pemateri pada pelatihan tersebut berasal dari unsur akademisi Universitas Negeri Gorontalo dengan materi manajemen keuangan UMKM, unsur pelaku UMKM Binaan Bank Indonesia dan Rumah Kreatif BUMN dengan materi strategi pengelolaan bisnis di era covid-19, unsur Dinas Pariwisata dan Ekonomi Kreatif Kabupaten Bone Bolango dengan materi inovasi 
pengelolaan usaha wisata pantai molutabu dan penguatan sadar wisata, dan unsur Perbankan (Bank Rakyat Indonesia) dengan materi sosialisasi program kredit usaha rakyat (KUR).

\section{HASIL DAN PELAKSANAAN}

Telah berhasil memberikan edukasi dan solusi terkait hal-hal apa saja yang dikeluhkan oleh para Pelaku UMKM yang ada di Desa Molutabu, Desa Helumo, dan Kelurahan Oluhuta terkait masalah cara mengelola keuangan, melakukan promosi hingga permasalahan modal. Adapun hasil Pelaksanaan Program Inti sebagai berikut:

1. Berdasarkan hasil survei yang dilakukan di kelurahan Oluhuta terdapat sekitar 30 UMKM yang terdapat di lokasi tersebut. Kemudian survei lanjutan dilakukan, kami telah mendata sebanyak 14 UMKM. Dari data yang telah diperoleh dapat menjadi acuan kami untuk melakukan Bimtek terhadap UMKM. Adapun Pelaku UMKM yang hadir dalam Bimtek terdapat 4 orang pelaku UMKM. 4 UMKM yang mengikuti Bimtek tersebut selanjutnya akan dilakukan pembinaan dalam pengembangan UMKM di Kelurahan Oluhuta.

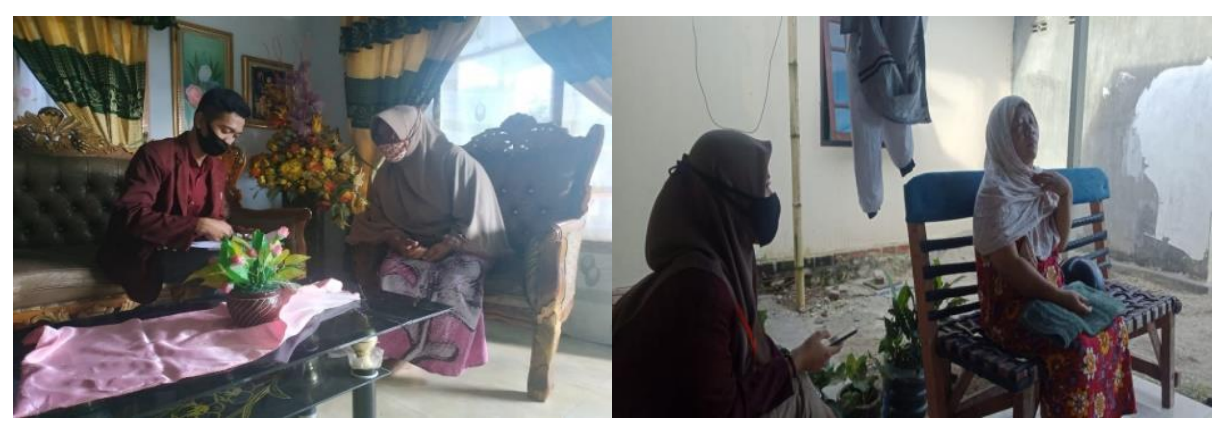

Gambar 1 Observasi dan wawancara Kelurahan Oluhuta 


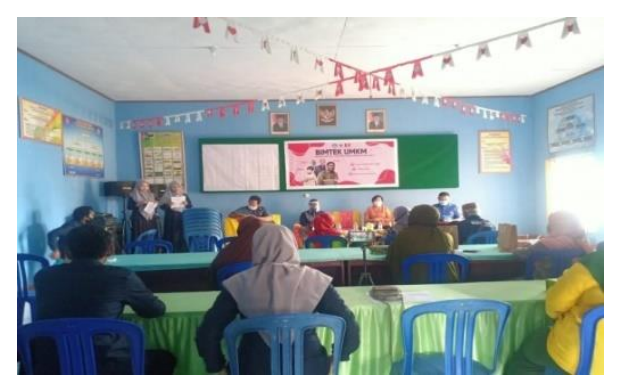

\section{Gambar 2 Bimtek UMKM Kelurahan Oluhuta}

2. Berdasarkan hasil survei yang dilakukan di Desa Helumo terdapat sekitar 40 UMKM yang terdapat di lokasi tersebut kemudian melakukan Pelatihan strategi pengelolaan dan manajemen keuangan UMKM yang dihadiri 15 orang pelaku UMKM di Desa Helumo. Dalam kegiatan ini, yang menjadi Pemateri dalam kegiatan tersebut adalah Ibu Elizabet Mariana Mahieu, yang juga salah satu Tokoh penggerak UMKM di Kab. Bone Bolango. membawakan materi strategi pengelolaan UMKM dan juga Bapak Amir Lukum, S,Pd., M.SA yang membawakan materi manajemen keuangan dalam UMKM. Kemudian terdapat 5 orang pelaku UMKM yang selanjutnya dilakukan pendampingan dalam penyusunan pembukuan.

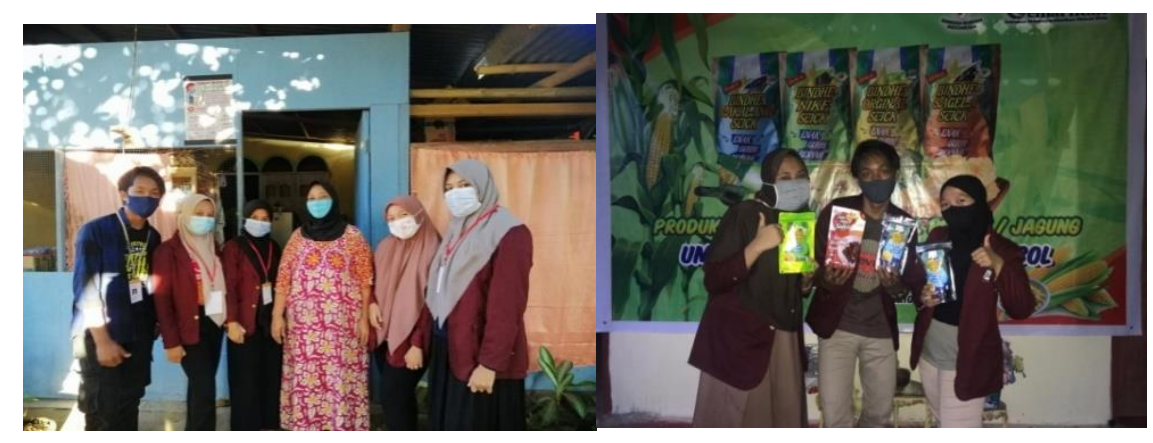

Gambar 3 Observasi dan wawancara Pelaku UMKM di Desa Helumo 


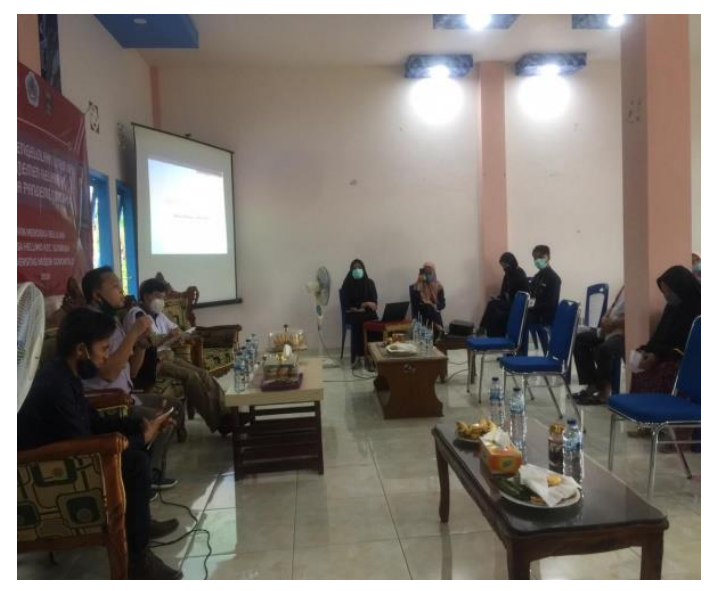

\section{Gambar 4 Pelaksanaan Pelatihan UMKM desa Helumo}

3. Berdasarkan hasil survei yang dilakukan di Desa Molutabu terdapat sekitar 50 UMKM yang terdapat di lokasi tersebut. Kemudian survei lanjutan dilakukan, kami telah mendata sebanyak 21 UMKM kemudian Menyelenggarakan pelatihan strategi pengelolaan UMKM di era pandemic covid-19 guna menjawab permasalahan para pelaku UMKM. Pemateri pada pelatihan tersebut berasal dari unsur akademisi Universitas Negeri Gorontalo dengan materi manajemen keuangan UMKM, unsur pelaku UMKM Binaan Bank Indonesia dan Rumah Kreatif BUMN dengan materi strategi pengelolaan bisnis di era covid19, unsur Dinas Pariwisata dan Ekonomi Kreatif Kabupaten Bone Bolango dengan materi inovasi pengelolaan usaha wisata pantai molutabu dan penguatan sadar wisata, dan unsur Perbankan (Bank Rakyat Indonesia) dengan materi sosialisasi program kredit usaha rakyat (KUR). Pelatihan tersebut dihadiri oleh 21 Pelaku UMKM, Setelah Melakukan pelatihan selanjutnya kami melakukan pendampingan pada para pelaku UMKM. 


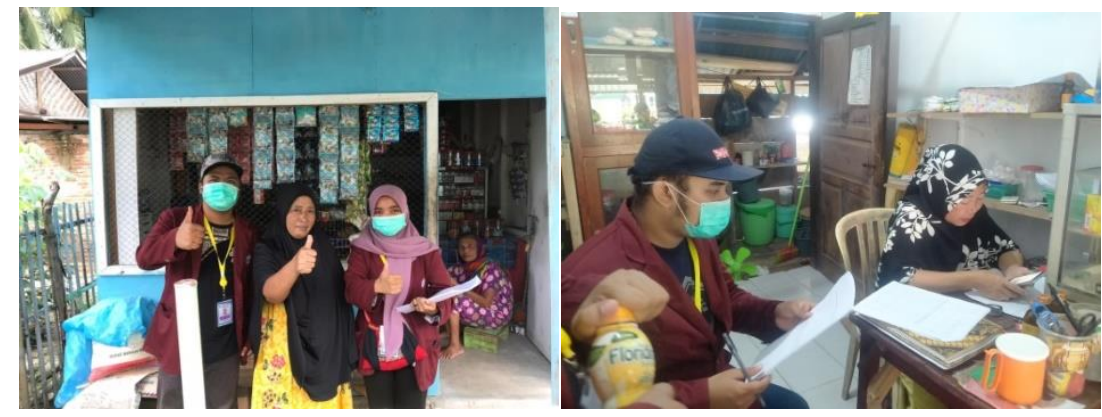

Gambar 5 Observasi dan Wawancara UMKM di desa Molutabu
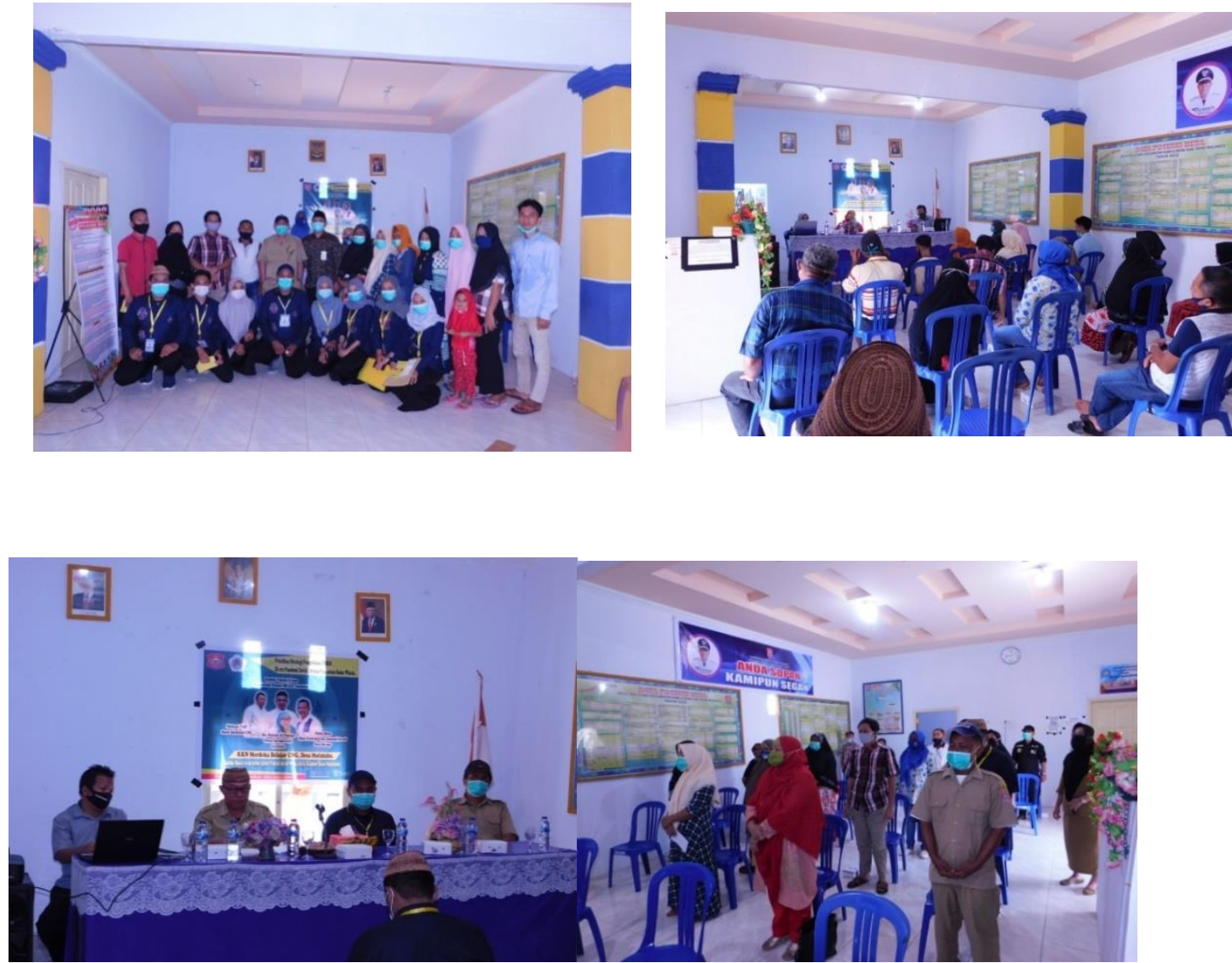

Gambar 6 Pelatihan UMKM di Desa Molutabu

\section{KESIMPULAN}

Dari kegiatan hasil pengabdian ini dapat diperoleh kesimpulan bahwasanya Pandemi Covid-19 benar-benar telah menjadi ancaman yang sangat serius bagi para pelaku UMKM untuk kelangsungan usaha mereka, maka dari itu seyogyanya UMKM berhak untuk mendapatkan dukungan dan dorongan dari berbagai pihak termasuk Univeristas Negeri 
Gorontalo. Dari kegiatan pengabdian ini dapat membantu menjawab berbagai permasalahan yang sudah menjadi kegelisahan dari pelaku UMKM itu sendiri.Kegiatan pendampingan yang intens dan serius sangat diharapkan untuk pengembangan UMKM kedepannya.

\section{UCAPAN TERIMA KASIH}

Terima kasih kepada Lembaga Penelitian dan Pengabdian pada Masyarakat (LPPM), Universitas Negeri Gorontalo atas dukungan Dana Pengabdian PNBP 2020.

\section{DAFTAR PUSTAKA}

Agustina Prativi Nugraheni, O. L. (2020). STRATEGY OF SMEs IN THE COVID-19 PANDEMIC PERIOD. Jurnal Akuntansi \& Perpajakan.

Benny Prayudi, Ida Budiarty, Irma Febriana (2019). Analisis Penyerapan Tenaga Kerja Pada Industri Batu Bata Di Kecamatan Seputih Mataram Kabupaten Lampung Tengah.

Erwan-Agus (2007). Mengkaji Potensi Usaha Kecil dan Menengah (UKM) untuk Pembuatan Kebijakan Anti Kemiskinan di Indonesia. https://doi.org/10.22146/jsp.11009

Gangi, F., Meles, A., Monferrà, S., \& Mustilli, M. (2018). Does corporate social responsibility help the survivorship of SMEs and large firms? Global Finance Journal, 100402. https://doi.org/10.1016/i.gfj.2018.01.006

Ghassani, N. (2015). Kemitraan Pengembangan UMKM. Kebijakan Dan Manajemen Publik, 3(2), 142-151. Retrieved from http://journal.unair.ac.id/download-fullpaperskmp16cb8512a4full.pdf

Grootaert, C., Narayan, D., Jones, V. N., \& Woolcock, M. (2004). Measuring social capital: An integrated questionnaire. The World Bank. 
Haryono, N. (2016). Pengembangan Usaha Mikro Kecil dan Menengah melalui Program Corporate Social Responsibility Memasuki Pasar Bebas. Jejaring Administrasi Publik, 8(1),887-898. Retrieved from http://journal.unair.ac.id/download-fullpapersadmp82d74b3aa6full.pdf

Haryono, N. (2016). Pengembangan Usaha Mikro Kecil dan Menengah melalui Program Corporate Social Responsibility Memasuki Pasar Bebas. Jejaring Administrasi Publik, 8(1), 887-898. Retrieved from http://journal.unair.ac.id/download-fullpapersadmp82d74b3aa6full.pdf

Lies,M.H dan Devi-Agustin (2019). Pengaruh Perkembangan Usaha Mikro, Kecil, dan Menengah Terhadap Pendapatan Nasional Pada Sektor UMKM di Indonesia.https://doi.org/10.23960/jep.v8i2.45

Pakpahan, A. K. (2020). COVID-19 dan Implikasi Bagi Usaha Mikro, Kecil, dan Menengah

Thaha, A. F. (2020). DAMPAK COVID-19 TERHADAP UMKM DI INDONESIA. JURNAL BRAND, 147-153. 